\title{
Qualitative and Quantitative Survey and Suggested Management Strategy of Hospital Solid Waste at Hormozgan Province, Iran
}

\section{Mohsen Dehghani ${ }^{1 *}$, Majid Vafadar ${ }^{2}$}

${ }^{1}$ Department of the Environment, Islamic Azad University, Bandar Abbas Branch, Bandar Abbas, Iran

${ }^{2}$ Environmental Science, Hormozgan Provincial Directorate of Environment Protection, Bandar Abbas, Iran

Study Area: Bandar Abbas, Iran

Coordinates: $27^{\circ} 11^{\prime} \mathrm{N} ; 56^{\circ} 16^{\prime} \mathrm{E}$

Key words: Hazardous Waste, Infectious Wastes

\section{Abstract}

Medical wastes always need special attention because of having infectious and hazardous compositions for the environment in the solid wastes management system. One of the most fundamental elements in planning and implementing a correct medical wastes management program is being aware of quantitative and qualitative amounts of medical wastes. The present piece of work is a temporal descriptive type which was carried out for examining medical wastes in Hormozgan province from qualitative and qualitative based on collecting data from 15 hospitals, field visits and sampling and analyzing results. Results revealed that in studied hospitals $2556 \mathrm{Kg}$ medical waste is coming out every day. According to a number of total occupied beds in studied hospitals, it shows every bed makes $83.1 \mathrm{Kg}$ medical waste that are infectious and hazardous wastes from 9.45 percent of this number. According to results of the study, management of hazardous medical wastes and destroying them is one of the worrisome and important problems of Hormozgan province that needs special attention for municipal planners and managers.

\section{Introduction:}

In the recent decades human lifestyles and their respective consumption pattern have triggered numerous mass of different types of waste (La Grega et al., 2001; Yong, 2009). These wastes are sometimes acting as a serious threat to human and other living creatures' survival. Hazardous wastes usually composed of either explosive, combustible, erosive, interactive or toxic and mostly is subcategorized in these categories: radioactive, chemical, combustible, biologic and explosive wastes (Albertoni et al., 1992; La Grega et al., 2001). Hospitals, laboratories and medical research centres are one of the crucial sources of biologic wastes. The collection, disposal or recycling technology of these materials must be different in comparison with municipal and domestic wastes (Ropeik \& Gray, 2002; Republic of Croatia, 2004). Recently, the World Health Organization has presented a relatively precise classification about medical wastes, according to which one can categorise them to general wastes, pathological wastes, radioactive wastes, chemical wastes, infectious wastes, pharmaceutical wastes and pressurised containers. Although a small portion of medical wastes is infectious and hazardous but the incorrect way of its management perhaps causes environment, soil and weather pollution (Philip, 2003). In recent years, concern over clinical waste has increased throughout the world. Improper management of clinical waste poses a public health risk. Therefore, appropriate Clinical Waste Management (CWM) is a crucial issue for maintaining human and public health (Nema et al., 2011).

A mixture of such wastes with domestic wastes not only endangers citizens' health by spreading infectious factors, rather it pollutes environments in landfills. Furthermore, it makes impossible to recycle and process other wastes (Marinkovic et al., 2008). UN environment and development conference which was held in 1992 and caused to accept agenda 21, suggests a set of programs of waste management. A summary of those suggestions are:

- Prevent from producing wastes and reaching waste generation to minimum

- Reuseand recycle trash if possible

- Refining trash using an assured and reliable environmental way

- Dispose of final remains using burial method in pit, fenced and precisely planned spaces

*Corresponding Author: dehghani933@gmail.com 
Also, Agenda 21 stresses that generators of trash are responsible for refining and disposing of their own generated trashes finally, and every society has to bury its trashes inside its borders (Philip, 2003). The Clinical Waste Management practices cover all processes from the point of identification the wastes, to the place it is disposed of in an incinerator. Initial handling, collecting, transporting, disposing and monitoring of waste materials are collectively called waste management. The primary objectives of waste management are reducing the amount and hazards of waste. Reusing the waste through the provision of secondary raw materials and use of the waste as energy resource are other objectives of waste management (Mochungong, 2011). In table 1 European countries approach towards hygienic-medical wastes is presented.

Table -1: Portion of hygienic-medical wastes disposal methods (percent) in European countries

\begin{tabular}{llll}
\hline Method $\quad$ Year-> & 2010 & 2000 & 1993 \\
Incineration & $37 \cdot 3$ & 30 & 10 \\
Combustion & $25 \cdot 5$ & 35.6 & 46.6 \\
Refining 11 & 10 & 48.6 & \\
Burying inside the earth & 17 & 8.5 & 1.8 \\
Reusing & $4 \cdot 3$ & 5 & 7 \\
Recycling & 3.3 & 7.6 & 11 \\
Prevent from generation & 1.6 & 3.3 & 5 \\
& & &
\end{tabular}

Materials and methods:

This temporal descriptive research was done during the year 2010 to 2011 in 15 hospitals of Hormozgan province 7 hospitals in Bandar Abbas and 8 other hospitals in Bastak, Parsian, Bandar-e-Lenge, Bandar-e-Khamir, Hajiabad, Rudan, Minab and Jask. In order to examine the condition of collecting, temporal storing, segregating trashes, final disposal, training staff, disposal and etc, standard questionnaire given from the ministry of health and treatment and field visits were used. This questionnaire includes general and specif ic questions like a number of used and infectious beds, staff, microbe tests, method of collecting, storing, transporting and disposing of all types of medical wastes. For determining qualitative and quantitative amounts of generative wastes, sampling and analysing all types of wastes were implemented monthly continuously for a year. Since each of the hospital's amount of generated wastes of units is different for day to day, thus for resolving this problem and attaining true information the operation was repeated for three consecutive days and it was arranged to set one of those days visiting patients day. Quantitative amounts of total wastes, infectious, general (semi domestic) and sharp wastes was determined using a weighing method by platform scale as exactness of \pm 100 . in order to determine the qualitative condition of wastes, simultaneously amounts of weight percent of plastic, paper and cupboard, fabric, glass, metals, nutritious wastes and etc. were analysed in infectious and general wastes. During all the periods of study wastes density amounts were determined and recorded (WHO, 1999; WHO, 2001). Collected data were reported and analysed using descriptive indicators.

\section{Results:}

\section{General survey:}

The number of all the medical units in studied hospitals was 140 units. From all the 15 studied hospitals, 14 hospitals were administered by government and 1 hospital was private. Besides, there were total 1734 beds in the hospitals concerned in this study out of which only 1394 beds which wereactive.

\section{Collection and upkeep:}

According to the studies, 66.7 percent of the studied hospitals used plastic containers (plastic bags) and 33.3 of them used both plastic and steel containers in order to collect the waste. Temporary storage sites were not built based on a specific and constant pattern or standard in most of the hospitals. And as there is no appropriate cover, in many cases dangerous wastes are spread around because of rain and other climate factors.

\section{Transportation:}

The present study evidenced that 25 percent of these hospitals uses covered trucks whereas 18 percent of them uses covered pickups for transporting the waste. The medical waste is collected by the municipality in 87 percent of hospitals but in the rest, 13 percent;is collected by the hired companies. Only 7 hospitals out of the 15 studied ones have got an incinerator which is active despite some problems such as smoking and loss of appropriate staff. And the other 8 hospitals haven't got any incinerator. Based on the surveys, all of the studied hospitals separate infectious waste from other solid waste. Surprisingly, that none of the studied hospitals equipped appropriate procedures to exclude the waste.

\section{Quantities:}

The results indicate that there was a $2556( \pm 210) \mathrm{kg}$ waste production in the studied hospitals which was approximately $1 / 83( \pm 0.14) \mathrm{kg} / \mathrm{bed} /$ day and is much less than the average production rate in some of developed countries $(4.5 \mathrm{~kg} / \mathrm{bed} /$ day $)$. Based on the studies, the average waste production rate in Persian Gulf hospital is the highest rate with $3.20( \pm 0.21) \mathrm{kg} / \mathrm{bed} /$ day and that of Abalfazl hospital of Minab is the lowest one with $1.25( \pm 0.09) \mathrm{kg} / \mathrm{bed} /$ day.

\section{Hospital Waste Composition (Figure-1):}

According to the results derived from this study, 45.9 percent of hospital waste in Hormozgan province was the infectious waste, 53 percent of them was a general waste and only $1 / 1$ was a sharp waste. Therefore, an infectious waste rate of the province was $1788( \pm 136) \mathrm{kg} /$ day. The 
sharp waste rate was $42.8( \pm 32)$ and a general waste rate was estimated to be $2065( \pm 189) \mathrm{kg} /$ day. Besides, based on the results the density of hospital waste was $302 \mathrm{~kg} / \mathrm{m} 3$.

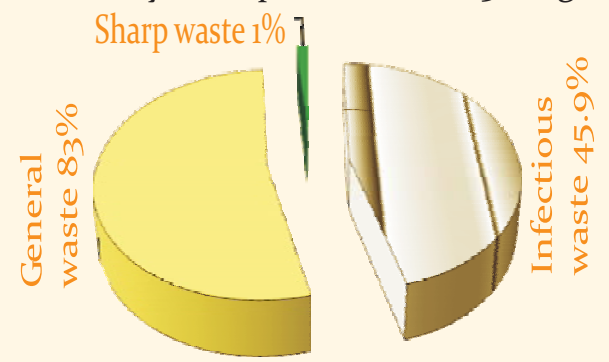

Figure -1: Waste generation rate in Hormozgan Province

Waste Quality Analysis (Figure-2):

According to the results of hospital waste study, nutrition and spoilable materials from 24.1 percent of hospital waste weight, paper 4.9, cloth 18.7, glass 1.5 and metals 2.6.

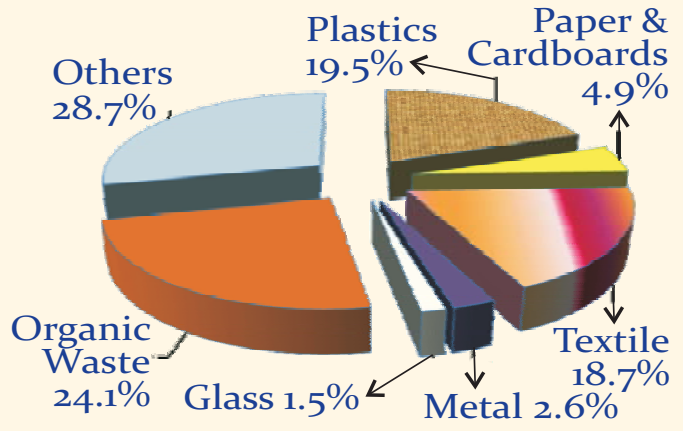

Figure-2: Non-infected medical waste composition in Hormozgan Province

\section{Assessment:}

On the basis of statistics on medical science university of Hormozgan the entire weight of hospital, medical and sanitary waste of was assessed to be $3896 \mathrm{~kg} /$ day. If the average rate of domestic waste production of Hormozgan province was $0.8 \mathrm{~kg} /$ day, then regarding the 1028190 population of Hormozgan, the entire waste production rate of the province would be 822000 tons. Considering how much the medical and hospital waste weighs in the presented study (3896 tons/day), then hospital waste would be only 0.5 percent of the entire domestic waste. Therefore, the produced hospital waste in one year would be 1422 tons.

Table -2: Hospital waste analysis in Hormozgan province

\begin{tabular}{ll}
\hline Parameter & mount \\
\hline - Waste production rate & $2356( \pm 210) \mathrm{kg} / \mathrm{bed} /$ day \\
$\begin{array}{l}\text { in the targeted Hospitals } \\
\text { Entire hospital waste of theProvince }\end{array}$ & $3896( \pm 371) \mathrm{kg} / \mathrm{bed} /$ day \\
- Average waste production rate & $1.83( \pm 0.14) \mathrm{kg} / \mathrm{bed} /$ day \\
- Maximum waste production rate & $3.29( \pm 0.21) \mathrm{kg} / \mathrm{bed} /$ day \\
Minimum waste production rate & $1.29( \pm 0.09) \mathrm{kg} / \mathrm{bed} /$ day \\
$\begin{array}{l}\text { Hospital waste percentage out of } \\
\text { entire Domestic waste of province }\end{array}$ & $0.5 \%$ \\
$\begin{array}{l}\text { Infectious waste rate } \\
\text { M }\end{array}$ & $1788( \pm 136) \mathrm{kg} / \mathrm{bed} /$ day
\end{tabular}

\section{Discussion:}

The present study indicates, the hospital waste production rate is not only different in the studied hospitals but is also different from the rate of other cities of Iran and other countries. The cause of such differences is mostly depending on various factors such as waste management process, type of the hospital services, the number of active beds, cultural and economic conditions of society and so on (La Grega et al., 2001). Hospital waste rates had been changing between $2,9 \mathrm{~kg} / \mathrm{bed} /$ day in some of the American hospitals. As per Eker \& Bilgili (2011) the average waste production rate in Turkey was about 2.113.83.

Tsakona et al. (2007) reported that the average rate of medical wastes production in Greece was equivalent to 1.9 $\mathrm{Kg}$ in lieu of each bed in 24 hours which has been found similar to the measured amount in Hormozgan hospitals. While in this research per head waste production in lieu of every bed was $1.83 \mathrm{Kg}$ in 24 hours. Jang et al.(2006) reported medical wastes production per head amount $1.49 \mathrm{Kg}$ in lieu of each bed every 24 hours in Korea and which was less than measured amount in our study. In Figure-3 average of produced medical wastes in Hormozgan province has been compared with the results of otherstudies.

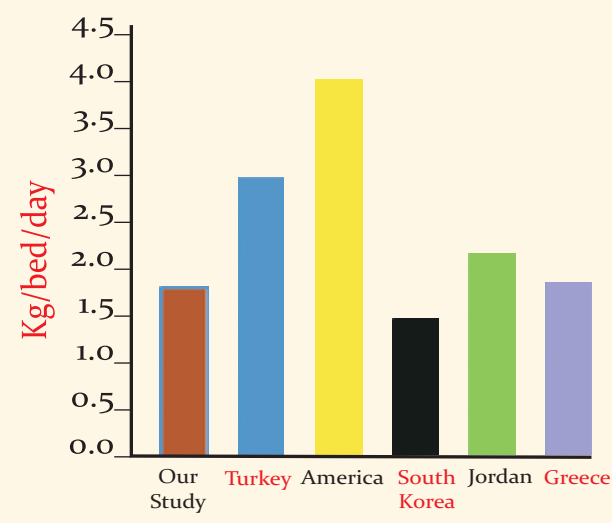

Figure -3: Comparison among Rates of Waste Generation and Hospital Waste in Different Country

In developing countries amount of 0.16 to $3 \mathrm{Kg}$ from each bed at every 24 hours and infectious wastes are about 63 percent and between 0.01 to $0.65 \mathrm{Kg}$ in lieu of every bed every 24 hours (Diaz et al., 2008). Bazrafshan \& Pour (2010) reported that in 2008-2009 among 14 active hospitals in Sistan and Baloochestan, infectious, general and sharp wastes in order were equivalent to $45.9,53$ and 1.2 percent of total produced wastes. These statistics were presented while according to accomplished studies in other countries about 10 to 20 percent of total medical wastes were counted as infectious and hazardous wastes. Motosso \& Schalch (2001) in the management of medical wastes study on Brazil showed that more than 50 percent 
of produced wastes were infectious. Sawalem et al. (2009) from Libya revealed that 72 percent of studied medical wastes were general and 28 percent of them were hazardous while in this study hazardous wastes were counted 47 percent of total weight of wastes. By considering current problems in the management department of medical wastes are always one of managers' and planners' main challenges, hence development, enhancement and amendment of this current condition is necessary. It seems problems which result from keeping trashes in temporal disposal locations, lack of segregation of wastes based on quality, lack of having incineration for all hospitals of Hormozgan, burying medical wastes and municipal wastes at the same place and lack of finding appropriate location for burying medical wastes of Hormozgan are the most important problems of wastes management that are needed to be take into consideration in order to reduce environmental and hygienic hazards.

\section{Acknowledgements:}

This article is product of researching plan named "quantitative and qualitative study of hospital wastes of Hormozgan" that was approved from department of environment of Hormozgan in 2010 and was accomplished by financial support of department of environment of Hormozgan. We appreciate the cooperation and contributions of respectful headquarter of department of environment of Hormozgan and other employees, workers and staffs of studied hospital whole heartedly.

\section{References:}

Albertoni, F., Ippolito G, Petrosillo N, Sommella L, Di Nardo V, Ricci, C., Franco, E., Perucci, C.A., Rapiti, E. \& Zullo, G. (1992): Needlestick injury in hospital personnel: a multicenter survey from Central Italy. Infect Control Hosp Epidemiol., 13(9):540-544.

Bazrafshan, I., \& Pour, M.F. (2010): Evaluation of the quality and quantity of hospital waste in the province in 88-1387. Zahedan J. Res. Med.Sci.1(38):26-32.

Diaz, L.F., Eggerth, L.L., Enkhtsetseg, S.H. \& Savage, G.M. (2008): Characteristics of healthcare wastes. Waste Manag. 28(7):1219-1226
Eker, H.H. \& Bilgili, M.S. (2011): Statistical analysis of waste generation in healthcare services: A case study. Waste Manag. Res.. 29(8): 791-796.

Jang, Y.C., Lee, C., Yoon, O.S. \& Kim, H. (2006): Medical waste management in Korea. J. Environ. Manage., 80:107-115

La Grega, M., Buckinham, A.P., \& Aevans, J. (2001): Hazardous Waste Management (2nd ed.). New York, USA: McGrawHill Company.

Marinkovic, N., Vitale, K., Holcer, N.J., Džakula, A., \& Pavic, T. (2008): Management of hazardous medical waste in Croatia. Waste Manag., 28 (6): 1049-1056o.

Mattoso, V.D., Schalch, V. (2001): Hospital waste management in Brazil:a case study. Waste Manag. Res., 19(6):567-72.

Mochungong, P.I.K. (2011): Environmental Exposure and Public Health Impacts of Poor Clinical Waste Treatment and Disposal in Cameroon. PhD Thesis, University of Southern Denmark.

Nema, A., Pathak, A., Bajaj, P., Singh, H. \& Kumar, S. (2011): A case study: biomedical waste management practices at city hospital in Himachal Pradesh. Waste Manag. Res., 29(6): 669-673.

Philip, L.R. (2003): Safe Management of Health-Care Waste. World Health Organization.

Republic of Croatia, (2004): Law on waste. Republic of Croatia: Off icial Gazette.

Ropeik, D. \& Gray, G., (2002): Risk. Houghton Mifflin Company.

Sawalem, M., Selic, E. \& Herbell, J.D. (2009): Hospital waste management in Libya: A case study. Waste Manag., 29(4): 1370-1375

Tsakona, M., Anagnostopoulou, E. \& Gidarakos, E. (2007): Hospital waste management and toxicity evaluation: a case study. Waste Manag., 27(7): 912-920.

WHO. (1999): Safe management of wastes from health-care activities. Geneva:Switzerland.

WHO. (2001): Health care waste management. Rapid assessment tool for country level. Second draft.

Yong, Z., Gang, X., Guanxing, W., Tao, Z. \& Dawei, J. (2009): Medical waste management in China: A case study of Nanjing. Waste Manag., 29:1376-1382. 